\title{
The Analysis of Code-Switching and Code-Mixing in a Fanfiction Entitled "Crazy Rich Chenle"
}

\author{
Shareen Vanessa ${ }^{1}$, I Wayan Mulyawan ${ }^{2 *}$, Ni Ketut Alit Ida Setyaningsih ${ }^{3}$ \\ ${ }^{[1[2][3]]}$ English Department, Faculty of Humanities, Udayana University \\ Denpasar, Bali \\ Email: wayan_mulyawan@unud.ac.id
}

\begin{abstract}
This article is entitled "The Analysis of code-switching and code-mixing in a fan-fiction entitled "Crazy Rich Chenle". This study aims to analyze the types of code-switching, types of code-mixing as well as the reasons for code-switching and codemixing. The data is taken from the fan-fiction entitled "Crazy Rich Chenle", written by Hadids and uploaded on the online reading platform known as Wattpad. The documentation method and note-taking technique are being used to collect the data. The data were analyzed using descriptive qualitative methods. This study uses the theory of Hoffman (1991) about types of code-switching and the theory proposed by Musyken (2000) about types of code-mixing. The result of this study showed that there are three types of code-switching and three types of code-mixing found and used by the characters in the fan-fiction "Crazy Rich Chenle". The characters in the fan-fiction "Crazy Rich Chenle" mostly used inter-sentential switching and insertion types of code-mixing.
\end{abstract}

Keywords: Code, code-switching, code-mixing, switching, mixing

\section{INTRODUCTION}

Language has a very important role in our life. We use language for communications. People nowadays speak multiple languages, perhaps one at home and another in the village (Wardhaugh 2011:93). Moreover, Wardhaugh argued that multilingualism is taken for granted, and switching from one language to another during a single conversation is common.

According to Meyerhoff (2006), speakers use a different language style depending on where they are, whom they are speaking with, and what kind of impression or persona they want to convey to their interlocutors. The choice of code also reflects how the speaker wants to appear to others, how they want to express their identity, or how they want others to view them. Likewise, Holmes (2013) stated that our speech provides clues to others about who we are, where we come from, and perhaps what kind of social experiences we have had.

In sociolinguistics, the term code is widely used. Any system that two or more people use for communications can be referred to as code (Wardhaugh 2011:84). People must then choose a specific code whenever they want to speak, and they may choose to switch from one code to another or mix codes even within short utterances. That creates new codes in a process known as code-switching.

Code mixing is a mixing of two codes or languages, usually without a change of topic. Code mixing often occurs within one sentence. One element is spoken in language A and the rest in language. Code-mixing is the change of one language to another within the same utterance or in the same oral or written text (B. Nababan, 1993; in Yuliana, Luziana, \& Sarwendah, 2015)

Code-switching, code-mixing, and the reasons for codeswitching and code-mixing in the fan-fictions "Crazy Rich Chenle" are the main focused of this study. The reason why fan fiction was chosen as the object of the research is that many fan-fiction authors used code-switching and codemixing in their stories. Other than that, fan-fiction authors mostly used informal language to make their stories more natural and understandable. That is why the fan-fiction was written by Hadids entitled "Crazy Rich Chenle," was chosen as the main data source for this study.

According to the above phenomena, two problems were discussed, as follow: 
1. What are the types of code-switching and code-mixing found in the fan-fiction "Crazy Rich Chenle"?

2. Why are the characters uses code-switching and codemixing?

\section{Research Method}

The fan-fiction entitled "Crazy Rich Chenle" was chosen as the main data source in this study. This fan-fiction is written by Hadids and it is posted on an online reading platform known as "Wattpad". "Crazy Rich Chenle" is a fanfiction that tells a story about nine rich high school students: Chenle, Yireon, Ryujin, Hyunjin, Felix, Heejin, Hwall, Chaeyoung, and Seungmin. This fan-fiction tells a story about their school life, strong friendship, family matters as a rich family, and their complicated love story. The characters of this fan-fiction switched and mixed their language most of the time when they interacted with each other. The switched and mixed language performed by the characters in this fanfiction interest the researcher. That is the reason why this fan fiction was chosen as the data source in this study.

The documentation method and note-taking technique were used in collecting the data in this research. Documentation is a method that use a written source such as magazines, books, and newspapers to collect the data (Sudaryanto, 1988; in Zaim, M., 2014). There are three steps to collect the data: First, read all of the chapters of the fanfiction "Crazy Rich Chenle". Second, find the utterances which have code-switching and code-mixing. After that, noted down each of the utterances

In analyzing the data, the identification method is used. The identity method is a data analysis method that its determiner device is from outside of the language and does not become a part of the language being researched (Sudaryanto, 1988; in Zaim, M., 2014). There are three steps in analyzing the data: First, read the collected data. Second, Classified the utterances according to their types in the form of tables. Third, analyze the data using the theory proposed by Hoffman (1991) about types of code-switching and the reasons for code-switching, as well as the theory proposed by Musyken (2000) about types of code-switching.

The mixed-method of formal and informal are used to present the analysis. The method is used because the data in this research is presented with words and tables. There are a few steps to present the data: First, The sorted data is present in a table according to their types. Second, the data is accompanied by the chapter and the types. After that, the data analyzed by words description

\section{Results AND Discussion}

Below is the analysis related to the types of codeswitching, types of code-mixing, and the reasons for codeswitching and code-mixing, as follow:

\section{Types of code-switching}

\section{Inter-sentential switching}

Data 1 (Chapter 2)

Heejin: Of course I know you, everyone in this class knows. Maaf soal Rachel dan yang lain, mereka cuma kadang terlalu pengen tau

Heejin uttered this utterance after seeing how Ryujin responded to Rachel's who asked about her true identity. Heejin started the first sentence of her utterance in English, and then she continued her utterance in Indonesian. Heejin switched her language in the sentence level, which means she started her utterance in English and continued the second sentence in Indonesian. That is why her utterance is classified as inter-sentential switching.

Data 2 (Chapter 15)

Chenle: Berhasil, tapi dia tau gua kayak gini cuma biar dia cemburu. She even told me you're a nice girl that I shouldn't mess with, she's right.

This utterance is uttered by Chenle when he talked with Ryujin on the school rooftop. Chenle's utterance can be classified as inter-sentential switching. The reason why it's classified as inter-sentential switching is that the language switched occurred at the sentence level. As seen in the table, Chenle switched his language in sentence level. He started the utterance in Indonesian, and then he continued with English in the second sentence. That is why his utterance is classified as inter-sentential switching.

\section{Emblematic Switching}

Data 3 (Chapter 12)

\section{Ryujin: Not too bad lah. Hwall tetep nomor 1 di kelas}

The utterance above is uttered by Ryujin. She uttered this utterance when Chenle asks her about her rank in the class. Ryujin responded to Chenle's question by saying, "Not too bad" as seen in the table, which classified her utterance as emblematic switching.

\section{Data 4 (Chapter 24)}

Nakyung: Asal percaya mah bisa kok. You can do it Ryujin!

The utterance above is uttered by Nakyung when she's talking with Ryujin and some other students. Here, Nakyung tried to give Ryujin some enlightenment. Nakyung's utterance above is classified as emblematic switching because Nakyung added a certain set phrase "You can do it," in her utterance. 


\section{Establishing continuity with the previous speaker}

Data 5 (Chapter 16)

Hwall: Yeah, thank you, come and watch the tournament on Sunday

Ryujin: Sure! By the way liat Hyunjin gak?

Hwall and Ryujin's conversation above can be classified as establishing continuity with the previous speaker. The reason is Hwall speaks entirely in English at first, so to keep the continuation of the conversation, Ryujin also responded in English, and she switched into Indonesian later on by saying, “...liat Hyunjin gak?". That is why the conversation between Hwall and Ryujin is classified as establishing continuity with previous speakers.

\section{Data 6 (Chapter 24)}

Chenle: You look prettiest in white

Yireon: Aww, thank you bub. Padahal aku mau beli gaun warna hitam

The conversation between Chenle and Yireon above took place in the shopping mall. They went to the shopping mall because Yireon needs to look for a prom dress. The conversation between Chenle and Yireon above can be classified as establishing the continuity with the previous speaker because, as seen, Chenle started his utterance in English. To keep the conversation going, Yireon responds in English then she continued her utterance in Indonesian. That is the reason why the conversation above is classified as establishing continuity with the previous speaker.

\section{Types of code-mixing}

\section{Insertion}

Data 7 (Chapter 3)

Chaeyoung: Ya di ruang ganti basket putri, lah? Disini ada CCTV

Chaeyoung uttered this utterance to answered Ryujin's question about where to change since they are preparing for the basketball extracurricular. As seen, Chaeyoung inserted the English word "CCTV" at the end of her utterance because there is no word in Indonesian equivalent with the term "CCTV". So her utterance is classified as insertion.

Data 8 (Chapter 4)

Chaeyoung: Gue juga gak bisa sore ini tapi kita harus hang
out bertiga kapan-kapan.

Chaeyoung uttered this utterance when she talked with both Heejin and Ryujin. There is no basketball practice that day, so Heejin asked Heejin and Ryujin to go for a hangout and welcome Ryujin as the new student. As seen, Chaeyoung inserted the English word "hang out" in her utterance, which makes her utterance classified as insertion.

\section{Alternation}

Data 9 (Chapter 9)

Eric: Jum'at parents meeting ya katanya?

Eric uttered this utterance to start a conversation with other students like Seungmin, Felix, and Chenle while they are on a second break. This utterance is classified as alternation because, as seen, Eric mixed his language in phrase-level by saying "parents meeting". Eric starts his utterance with the Indonesian word "jum 'at" then he adds the English phrase "parents meeting" then he finished his utterance in Indonesian by saying "...ya katanya?". That is why Eric's utterance is classified as alternation.

Data 10 (Chapter 11)

Mr. Kun: Beberapa dari ngajuin diri jadi Personal Assistant-mu, kualifikasinya gak ada yang memuaskan

Mr. Kun is the one who uttered this utterance. He uttered this utterance when he was with Chenle in the hotel's waiting room since they were at an event. This utterance of Mr. Kun can be classified as alternation. This utterance is classified as alternation because Mr. Kun mixed his language in phrasal level by adding the English phrase "personal assistant" in his utterance. That is why his utterance is classified as alternation.

\section{Congruent Lexicalization}

Data 11 (Chapter 12)

Ryujin : Hah gue kira itu cuma di film aja kalo anak konglomerat pasti dijodohin

Hyunjin: Ya katanya sih demi menjaga reputasi bisnis keluarga.

The conversation between Ryujin and Hyunjin took place in the shopping mall after Ryujin played in Timezone. As seen above, the three English words were modified into Indonesian pronunciation, which are the words "film", "konglomerat" and "bisnis". The modification involved pronunciation change, which is why the conversation above is classified as congruent lexicalization.

Data 12 (Chapter 25)

Chenle: Gue gak se-ekstrim Ayah lo sih sampe nasi goreng intel ke rumah Hyunjin

This utterance of Chenle took place on prom night when he talked with Ryujin. As seen above, there is a change in the pronunciation of the word "ekstrim". Chenle modified the 
English word "extreme" into Indonesian pronunciation, so it became "ekstrim". That is why this utterance is classified as congruent lexicalization because there is a pronunciation change involved in the lexical levels.

\section{Reasons for code-switching and code-mixing}

\section{Particular topic}

\section{Data 13 (Chapter 3)}

Felix: I heard Ayahnya Ryujin is tukang sampah, is that right? Gua pikir itu impossible.

This utterance took place when Felix talked to Chenle about the rumor of Ryujin's father, who worked as a garbage collector. As seen, Felix and Chenle talked about a specific person, Ryujin. So Felix mixed his language because he is more comfortable talking about someone in particular with a mixed language rather than talk in only one language.

\section{Data 14 (Chapter 9)}

Regina: Gak usah pura-pura bego, Pak Presiden. Its Shin Ryujin right?

Regina uttered this utterance when the rumor about Ryujin is Chenle's hidden fiance is spreading at school. So she asked Chenle about the truth, and she began to assume that Chenle's hidden fiance is indeed Ryujin. Regina's utterance above is classified as a particular topic because Regina is asking Chenle about a particular person. In this case, she is asking about Ryujin. That makes this utterance classified as a particular topic.

\section{Expressing group identity}

\section{Data 13 (Chapter 7)}

Hyunjin: Gimana mau bilang orang chat aja di read doang, lagian surprise biar relationship goals

Hyunjin uttered this utterance to Ryujin when he showed up in her house all of sudden without telling her. Hyunjin mixed his language is because he's more comfortable saying the English word "chat", "read", "surprise" and the English phrase "relationship goals" rather than saying those in Indonesian. He's more comfortable communicating that way, so his utterance is classified as group identity.

Data 14 (Chapter 21)

Hyunjin: Beda, Le. Budget pacaran gua gak nyampe 200 rebu, elu kan pacaran 200 rebu buat bensin doing

This utterance is uttered by Hyunjin when he is talking to Chenle about having a double date. As seen, Hyunjin added the English word "budget" unconsciously in his utterance rather than saying those in Indonesian. Other than that, both Hyunjin and Chenle were also more familiar with that word. That is why his utterance is classified as group identity.

\section{Real lexical need}

Data 15 (Chapter 10)

Mr. Kun: Kalau saya boleh jujur, akhir-akhir ini Chenle sedang moody

The utterance above was uttered by Mr. Kun, Chenle's assistant. Mr. Kun uttered the utterance in the car. This utterance can be classified as a real lexical need. Because, as seen, Mr. Kun used the English term "moody" in his utterance because the word "moody" is lacking in Indonesian, so Mr. Kun used the English term instead. That is why this utterance is classified as a real lexical need.

\section{Data 16 (Chapter 14)}

Ryujin: Terus pas beres makan gue diajak ke rooftop rumahnya, gak cuma berdua ada sodaranya juga

Ryujin was talking on the phone with her friend Daehwi the time she uttered this utterance. As seen above, Ryujin added the English word "rooftop" into her utterance. The main reason why she added the word "rooftop" is because the meaning will be hazy or vague in Indonesian. So she chose the English term instead. For this reason, her utterance is classified as a real lexical need.

\section{The intention of clarifying speech content}

Data 16 (Bonus Eps 3)

Chenle: Gua bisa pastiin dia masih mau sama lu, I can see it in his eyes whenever he talked about you

This utterance between Chenle and Ryujin took place when they met again in Bali, and they talked about Hyunjin. Chenle switched the language from Indonesian to English because he wanted to clarify the speech content, which is everything about Hyunjin, so Ryujin had a better understanding of what Chenle is trying to say. That is the main reason why Chenle's utterance is classified as the intention of clarifying speech content.

Data 17 (Bonus Eps 3)

Ryujin: Congratulations on your wedding ya, gue pengen banget kasih selamat ke Yireon tapi cuma bisa gue sampein ke lo

This utterance is uttered by Ryujin. This utterance took place when she met again with Chenle in Bali after a long time. Here, Ryujin congratulated Chenle on his wedding. She started her utterance by saying "congratulations on your wedding" and clarified the same message in Indonesian by saying "gue pengen banget kasih selamat ke Yireon..." that's why her utterance was classified as the intention of clarifying speech content. 


\section{Repetition used for clarification}

Data 18 (Chapter 15)

Chenle: Apapun alasannya, gua cuma mau ngasih tau kalo SMA itu masa-masa paling indah, Mr. Kun dan Mr. John bilang gitu, we don't have that much time left so create good memories here.

Chenle's utterance above occurred when he talked to Ryujin about the whole story between him and his hidden fiance, Yireon. This utterance is classified as repetition for clarification because Chenle said similar things to emphasize the message. It can be seen in this sentence "masa-masa paling indah" and the English phrase "so create good memories here." Both phrases have a similar meaning, which is that high school is the most beautiful time and create good memories when you are still in high school.

\section{Interjection (Inserting sentence fillers or sentence connectors)}

\section{Data 19 (Chapter 1)}

Chenle: You know, Ryujin, di dunia ini ada dua tipe manusia, yang pertama terlalu rajin dan yang kedua kurang kerjaan

Chenle's utterance above took place when he was with Ryujin on the school rooftop, seeing two students who came to school by helicopter. This utterance is classified as interjection because Chenle added the phrase "you know" at the very beginning of his utterance. The phrase "you know" has no grammatical value, and Chenle used it to gain Ryujin's attention.

\section{Being emphatic about something (express solidarity)}

Data 20 (Chapter 18)

Ryujin: Eh sorry sorry gue gak tau

This utterance of Ryujin took place when she was at Heejin's house. She uttered this utterance when Heejin told her that her parents divorced and her mother was re-married. As seen, Ryujin apologized because she asked about Heejin's mother without knowing her family situation. Therefore, Ryujin's utterance above is classified as empathic because she felt sorry for asking Heejin about her family.

\section{CONCLUSION}

Based on the foregoing discussion, it can be concluded that there are three types of code-switching found and used by the characters in the fan-fiction "Crazy Rich Chenle", namely: inter-sentential switching (19 data), establishing continuity with previous speaker (6 data), and emblematic (3 data).
As for the code-mixing, it can be concluded that there are also three types of code-mixing found and used by the characters in the fan-fiction entitled "Crazy Rich Chenle", namely: insertion (98 data), alternation (37 data), and congruent lexicalization (12 data).

There are 7 out of 10 reasons for code-switching and code-mixing found in the fan-fiction "Crazy Rich Chenle", namely: expressing group identity (66 data), particular topic (46 data), real lexical needs (43 data), intention of clarifying speech content (5 data), repetition of clarification (5), interjection (2 data) and showing empathy (2 data)

\section{REFERENCES}

[1] Grosjean, F. and Li, P., 2013. The psycholinguistics of bilingualism. John Wiley and Sons.

[2] Hoffmann, C., 2014. Introduction to bilingualism

[3] Holmes, J., 2013. An introduction to sociolinguistics. Routledge.

[4] Hudson, R.A., 1996. Sociolinguistics. Cambridge university press.

[5] Meyerhoff, M. (2006). Introducing sociolinguistics. Routledge

[6] Wardhaugh, R., 2011.An introduction to sociolinguistics (Vol. 28). John Wiley \& Sons.

[7] Zain. M., 2014. Metode penelitian bahasa: Pendekatan structural

[8] Yuliana, N., Luziana, A.R. and Sarwendah, P., 2015. Code mixing and code-switching of Indonesian celebrities: A comparative study. Lingua Cultura, 9(1), pp.47-54. 